\title{
Genetic Technique
}

National Cancer Institute

\section{Source}

National Cancer Institute. Genetic Technique. NCI Thesaurus. Code C16623.

Chromosomal, biochemical, intracellular, and other methods used in the study of genetics, including RNA and DNA chemistry. 